(0)

\title{
Utopian and Dystopian Homecomings in Olley Maruma's Coming Home and Shimmer Chinodya's Harvest of Thorns
}

\author{
Tanaka Chidora and Sheunesu Mandizvidza
}

\begin{abstract}
The two novels chosen for this paper represent divergent versions of homecoming. Most interestingly, Shimmer Chinodya's Harvest of Thorns (1989), a victim of scathing attack by cultural nationalists for its suggestively anti-establishmentarian title, and Olley Maruma's Coming Home (2007) are novels written at different times and feature two different characters whose versions of homecoming do not agree with their particular "callings." The central character in Harvest of Thorns, Benjamin, is an exguerrilla of the Second Chimurenga (the war of liberation that ushered in Zimbabwe's independence in 1980), who is depicted by the author as having failed to integrate into the "home" he was fighting for. This dystopian depiction of the home to which Benjamin returns after the war does not agree with the clichéd rhetoric of nationalist narratives that see the birth of the new nation as the pinnacle of nationalist achievement. On the contrary, Coming Home was written by a euphoric homecoming author and intellectual; his narrator is also "coming home" (and celebrates all the associated nationalist utopias of that time) at a period leading to 1980. But why would Maruma write Coming Home in 2007, a time when the majority of Zimbabweans were exiting home? These divergent views beg for closer analysis of the texts, especially focusing on how Harvest of Thorns shatters a dominant nationalist narrative while Coming Home desperately reconstructs it.
\end{abstract}

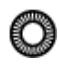

Coming Home (2007) by Olley Maruma and Harvest of Thorns (1989) by Shimmer Chinodya are novels that feature two focal characters whose versions of homecoming are deeply divergent. The analysis contained in this paper is made with an awareness of the tendency to foreground the cultural nationalist standpoint that has dominated the writing and evaluation of Zimbabwean literature, a tendency that is a way of writing and critiquing African literature ostensibly from an African perspective, at the expense of divergent perspectives. In the Zimbabwean case, this means producing and analyzing literature in a way that largely aligns with Zimbabwean nationalism. Zimbabwean nationalism is embodied by the Zimbabwe National African Union (Patriotic Front) (ZANU [PF]). ${ }^{1}$ Coming Home, written by a euphoric homecoming author and intellectual, and

\footnotetext{
${ }^{1}$ The ZANU (PF) is the party that has been at the helm of Zimbabwean politics since the days of the liberation struggle against white settler rule. Since formal independence on 18 April 1980, the party, led by Zimbabwe's only president so far, Robert Mugabe, has won virtually every election.
} 
featuring a narrator, Simon, who "comes home" amid the celebration of nationalist utopia in the period leading towards independence in 1980, finds endorsement within cultural nationalist scholarship. Maruma was born in 1953 and graduated with a degree in law from the University of Kent, England. Like Simon, he came back to Zimbabwe in the lead-up to independence on 18 April 1980, after which he became a well-known filmmaker and author. As one online critic observed, Maruma was regarded as a fierce nationalist until his death in 2010 (Kanengoni).

The approach towards home in Harvest of Thorns is more critical of nationalism than that in Coming Home. Benjamin, the central character in Harvest of Thorns, is an ex-guerrilla of the Second Chimurenga (the war of liberation that ushered in Zimbabwe's independence), who fails to integrate into the "home" he was fighting for. This dystopian depiction of the home to which Benjamin comes back after the war does not agree with the clichéd rhetoric of nationalist narratives. ${ }^{2}$ According to Sabelo J. Ndlovu-Gatsheni, this rhetoric claims that "real" development began when the "children of the soil" and the spirits of those who died in the war were allowed to come back to the home from which colonialism had alienated them (1148). "Children of the soil" is an autochthonous term associated with Zimbabwean nationalism that divides people into insiders (black patriots) and outsiders (black sell-outs and whites). ${ }^{3}$ The guerrilla warfare that led to the reclamation of home from colonial rule is the central narrative in the nationalist imaginary of ZANU (PF). Alexio, Wilson Katiyo's central character in the novel A Son of the Soil (1976), is another good example of a nationalist who fits within the ZANU (PF) imaginary. As Robert Muponde points out, Alexio has received positive criticism for being a revolutionary, whereas those who "do nothing" or are sceptical are criticised negatively (Some Kinds 44). The most prominent "do nothing" examples are Lucifer in Charles Mungoshi's novel

\footnotetext{
${ }^{2}$ See Ranger for a further discussion of Zimbabwean nationalist history.

${ }^{3}$ The phrase "sons of the soil" is particularly common in eulogies for those deemed to be "patriots" by the ZANU (PF).
} 
Waiting for the Rain (1975) and the inhabitant of the house of hunger in Dambudzo Marechera's novella The House of Hunger (1978), both of whom choose not to identify with home. These two are harshly criticised in nationalist Zimbabwean literary criticism and condemned for being anti-Zimbabwe. ${ }^{4}$

"Home" may refer to an epistemological terrain which collocates with nativist and essentialist discourses. Thus, being "at home" may sometimes connote thinking that is homebound. "Homecoming," therefore, can be understood as the physical return to one's home country from a foreign one or a "return to origins" in an ideological sense. The discourse of "pure origins" is not only essentialist, nativist, and militant but also potentially dangerous, exclusionary, and xenophobic. Any return to an undiluted and pristine precolonial past is not only impossible but quite dangerous. The question, then, is how does someone construct a coherent identity and home in a world where people and ideas are usually in circulation? "Home-returning projects" in a postcolonial age, where home should not be understood in terms of geographically-bounded space only, ought to be treated with suspicion (AbuShomar 2). Home, as a concept, has its own epistemologies that point to authenticity of culture, history, language, and identity. In other words, home can be linked to monolithic "modern" certainties and essentialized constructions of identity within the closed borders of a culture and a physical place. Not returning home, therefore, forces us "to rethink the rubric of our old concepts, monolithic discourse and epistemologies" (Abu-Shomar 3). It is a refusal to return to the parochial and limiting claustrophobics of home. The texts chosen here communicate two positions. Coming Home operates within the ambit of nationalist historiography and depicts home as a utopian space to which its children are happily returning. Harvest of Thorns, on the other hand, subverts the nationalist,

\footnotetext{
${ }^{4}$ The first full volume of critical work on Zimbabwean literature, Those Years of Drought and Hunger (1982), was authored by Musaemura Zimunya. It set a standard of labelling those characters who do not adhere to nationalist ideals as sell-outs. Subsequent critical volumes such as Rino Zhuwarara's An Introduction to Zimbabwean Literature in English (2001) entrench this tradition in the criticism of Zimbabwean literature.
} 
nativist, and essentialist projection of home by depicting it in dystopian images with seeds for both psychological and physical exile.

ZANU (PF) nationalism is premised upon an essentialized construction of home, within the geographically-bounded space called Zimbabwe that is said to belong to the "sons of the soil." The discourse of "returning" to Zimbabwe and "returning" Zimbabwe to its "sons" is central to this nationalism and has characterized land politics post-1999. The soil needed to be returned, as argued by ZANU (PF), to its "rightful" owners in order to complete the process of decolonization that started with the Chimurenga War. This is the return to which Coming Home still alludes and in favour of which Maruma writes twenty-seven years after independence, implying that a return and a home that do not abide by ZANU ( $\mathrm{PF}$ ) nationalist constructs cannot be real. Crucial to the returning of the homes of the sons of the soil is the question of belonging, which entails "authentic national subjects and creation of patriotic citizens" (Ndlovu-Gatsheni 1140). This authenticity of identity and space which is usually deployed in issues of belonging is what Chinodya challenges in Harvest of Thorns.

The post-2000 period in Zimbabwe was characterized by intense jostling and polarized views about belonging and the meaning of home. Maruma's Coming Home was published when much of the literature on Zimbabwe's socio-economic and political realities concurred that the country was going through the throes of hardships and uncertainty. ${ }^{5}$ The novel presents a home that is incongruously characterized by hope and certainty, founded on the ZANU (PF) government's nationalist myth. This is a home that Maruma dredges from the past and foists on the present as a legitimate foundation of national identity formation, as if to suggest that the current conditions are imaginary and not worthy of focus. Like the politics that energized it, literature during this time found itself taking sides

\footnotetext{
${ }^{5}$ Amanda Hammar, Brian Raftopoulos and Stig Jensen's Zimbabwe's Unfinished Business: Rethinking Land, State and Nation in the Context of the Crisis (2003) and Brian Raftopoulos's "The Crisis in Zimbabwe, 1998-2008" (2009) are publications which generally concur on the presence of a crisis in Zimbabwe during the post-2000 decade.
} 
with certain national identity constructions, especially those centred on ideas to do with land redress and sovereignty.

During the post-2000 crisis period, characterized by an economic implosion, political uncertainty, and widespread social problems that posed a serious threat to the ruling party's hegemony, ZANU (PF) looked to a revived nationalist and patriotic history to remain in power. This patriotic narrative found its way into some post-2000 literature, as in Nyaradzo Mtizira-Nondo's The Chimurenga Protocol (2008), Mashingaidze Gomo's A Fine Madness (2010), or Agrippah Mutambara's The Rebel in Me (2014). These novels import the ZANU (PF) discourse wholesale into literature. However, this acquiescence to nationalist hegemony is not the end-all of Zimbabwean literature, its creation, or its criticism. For instance, Muponde and Ranka Primorac's Versions of Zimbabwe: New Approaches to Literature and Culture (2005) is an attempt to subvert a patriotic reading of literary texts by foregrounding minority positions in the analysis of notable Zimbabwean literary texts. The narrative they subvert is that which is pivotal to ruling party rhetoric, a narrative which is subjected to "omissions, additions and simplifications" to serve ZANU (PF) interests, while simultaneously working against the opposition and conveniently writing it out of participating in and authoring the nation (Muponde and Primorac xiii). This makes Zimbabwe enter "the future by re-enacting the past in ways which are far from being purely discursive" (Muponde and Primorac xiv). While re-enactments involve a combination of imagination and historical fact, for Muponde and Primorac, the sort of re-enactment that ZANU (PF) indulges in is far from the aesthetic combination of imagination and history; it is dangerously bizarre and faulty but still serves the purpose of entrenching ZANU (PF) hegemony in Zimbabwe's body politic. 
Maruma spent the war days in Britain attaining an education and came back home during the transitory period of the Lancaster House talks. ${ }^{6}$ He was fiercely nationalist and patriotic in approach and considered himself an avowed panAfricanist, penning articles in the state-sponsored press in support of the ZANU (PF) government and its leadership. In Maruma, we see a combination of the most strident support for and obsequious belief in the ruling party and what it sought to project as the force best suited to move the country forward. This was apparent in the preponderance of nationalist rhetoric in Maruma's various roles as a filmmaker, reporter, farmer, and historian.

Like state (read: party) intellectuals and historians Tafataona Mahoso, Vimbai Chivaura, Aeneas Chigwedere, and Stan Mudenge, Maruma took every opportunity to fight for nationalist and patriotic ideals in the process of imagining and authoring the nation (Ranger 224). He extended this to creative writing, and Coming Home is one such output. The novel has a political significance which is "tied up with its subtle political hegemonic function in which it celebrates and props up the ZANU (PF) government's revived race-inspired nationalism" (Nyambi 141). Semi-autobiographical and with a past-present, colonialindependence setting, Coming Home is a story about the returning native. Like Simon, Maruma spends some time in Britain and thinks this gives him a distinct advantage over most Zimbabweans in exilic discourse. He believes himself to be qualified to cast aspersions on exile and justified in condemning its inhospitable nature. As a recent returnee, Maruma's nostalgic conception of home and his belief in the influence of nationalism as a magical gelling ingredient for the nation is understandable. The myth of oneness and progression that he seeks to popularize had worked to some extent in the liberation struggle and might still

\footnotetext{
${ }^{6}$ The Lancaster House Agreement was signed on 21 December 1979. It was a product of negotiations that brought formal and recognized independence to Zimbabwe (formerly Rhodesia). The parties that were represented at these talks were the Patriotic Front (led by Joshua Nkomo), ZANU (represented by Robert Mugabe), the settler Rhodesian government, and the British Government. After independence, in 1987, the Patriotic Front (PF) and ZANU signed a unity accord that saw the two parties becoming one under the name ZANU (PF). Mugabe became president of Zimbabwe, and Nkomo became vice-president. This marked the entrenchment of Mugabe's hegemony, which persists up to this day.
} 
work in this uncertain transitory stage (Vambe 259). Maruma's Coming Home, therefore, operates as a metanarrative that foregrounds the heroic exploits of the country's liberation fighters who, through the liberation struggle, are said to have created a home for black people which enabled them to come back home both physically (from exile) and symbolically (from feelings of alienation).

Chinodya's Harvest of Thorns, on the contrary, is not a metanarrative, centred as it is on the life of an ordinary young freedom fighter before, during, and after the war. Instead of being a war novel, with the inevitable features that war narratives assume in Zimbabwe, Harvest of Thorns attempts to question and challenge the rhetoric of ZANU (PF) nationalism. The novel reflects on the ordinary and smaller details of growing up in the townships of Rhodesia in the 1960s: courtship and love, together with the inconvenient truths of life during the war, which involve carrying a gun as a guerrilla, shooting people, and trying to remain alive. The collection of utopian nationalist ideologies that inform ZANU (PF) rhetoric remains peripheral. Benjamin, therefore, is a combatant, but not one in the frame of nationalist narrative that puts the nation (which is to say a ZANU [PF] nation) ahead of the self. Benjamin's war experiences make him realize how the war is primarily about survival; this contrasts with Simon's conception of struggle and home, which is based on ideas about war that develop far away from where the fighting takes place. Benjamin realizes that there is nothing selfless to the struggle, which exposes to scrutiny Simon's obliviousness to the realities of which Benjamin seems acutely aware.

Benjamin is one of the many individuals who became guerrillas by leaving home. What makes Benjamin's outward movement different from Simon's (and others' migration to Europe and North America) is that Benjamin goes out with the notion of training to fight and come back and make home a better place, whereas Simon goes out to come back only when home has already become better. The irony is that Benjamin, who goes out and comes back to fight, does not find home a better place, yet Simon thinks it has improved. In a reflection of typical 
guerrilla training, Benjamin crosses into neighbouring Mozambique to receive training and then returns to Rhodesia to fight the war as a way of constructing a new home with a new name (Primorac 126). If Harvest of Thorns is to be regarded as a war novel because it contains the ideologies of the war, then it fails to be a war novel. If we, however, regard it as a war novel because its chronotopes contain "space-time inhabited by armed combatants and/or those training to be combatants in the Second Chimurenga" (Primorac 127), then it has succeeded in this regard. What we find interesting is that the refusal of the novel to fit within the framework of the nationalist narration of war in Zimbabwe, which depicts a utopian home to which the combatants are happily and heroically returning, is a preparation for the dystopian character of home after the war itself. Such a preparation for dystopia is absent in Coming Home, which is predominantly utopic and refuses to see anything other than the promise of independence.

Politically, Benjamin's growth of self-awareness owes more to the contingencies of life than to the greater political education that sons of the soil acquire. He is not even sure about the phrase "son of the soil" and joins the war because he does not have anywhere else to go (Chinodya 99). In Zimbabwe's war narratives, guerrillas often acquire heroic status, but Benjamin (whose war name is "Pasi NemaSellout" or "Down with Sell-Outs")7 remains a civilian and a combatant. He is a civilian because he lacks the military hardness and commitment of a guerrilla character in nationalist narratives: at one point, when he is asked to kill a female spy, he thinks of his mother; at another, the death of a female comrade sends him into an interior monologue that reads like a letter to his mother (Chinodya 148). This failure to fully embrace war prefigures his failure to completely come back home at the end of the struggle. While the larger national

\footnotetext{
${ }^{7}$ In the war, guerillas assumed new war names. Benjamin's war name, "Pasi NemaSellout," is a message to sell-outs (those who give away information about guerillas to Rhodesian soldiers) - a threat that sell-outs would be brought down ruthlessly or killed. In the post-2000 dispensation in Zimbabwe, "sell-out" has assumed new meanings but predominantly refers to opposition politicians or those who do not agree with Mugabe and his wife, Grace, regardless of whether they are from ZANU (PF) or not. Sometimes, it is used to derogatorily refer to those who flee economic hardships and political turmoil in Zimbabwe to other countries that are considered perennial enemies of Mugabe's Zimbabwe by Mugabe himself.
} 
affairs of war are foregrounded in many war narratives, in Harvest of Thorns the concerns of the guerrillas are sex, urinating, staying warm, and, crucially, staying alive.

Despite its overriding nationalist drive, Coming Home countertextually implies uncertainty in the nationalist war when Tapfuma, an ex-combatant friend of Simon, initially appears "strong, healthy and very much alive" (112), but, a few paragraphs later, we are told that "his eyes looked red and bleary, as though he had gone without sleep for several days" (113). Such contradictory depictions of an ex-combatant ironically reveal the pitfalls of nationalist narration. Maruma's obsession with nationalist correctness makes him blind to the issues that militate against this kind of narration. In the end, we get the feeling that Maruma might have trapped himself unawares. How can one be healthy and alive yet move around with bleary eyes? Unlike Benjamin, Maruma's narrator seems to know more about the forces that are at play in the unfolding of his country's independence. In fact, Maruma's narrator speaks with more authority than Chinodya's ex-combatant, which in itself ought to make the reader suspicious.

Simon's belief that his unfortunate exilic experiences give him the licence to speak with authority on the home he barely knows is a major flaw in the novel's narrative logic. It is naive for Simon to think, at the point of return, that home is better just because Britain is a huge let-down. Home is a mere myth that he nurses to help him survive exile; he attempts to will it into existence, as it were, by blindly glorifying it. The past-present dichotomy that breathes life into the narrative and to which Maruma clings through Simon is unfortunately the narrative's biggest shortcoming: in Maruma's hands, it glorifies rather than analyzes the past and places Simon in a position where he seeks out and even sees a past home in the present when, in reality, it is not there.

In light of his political beliefs, it is telling that Maruma, in 2007, has to retrace the story of the transition to independence and gloss over its related problems. If some latitude should be afforded the returnee in his glorified 
conception of home in 1980, no such slacking should be allowed in 2007. In fact, over the intervening years, research has debunked the myth of a glorious transition. It has also interrogated the myth of nationalism to which the state was moored and shown that notions of homogenous black subjects with common aspirations were patently false (Vambe 258). For Maruma and the other purveyors of nationalist and patriotic discourse to insist on this, even back in 1980, sets a dangerous precedent by authorizing a certain historical (un)truth which essentializes blackness and home.

The essentialization of home and homogenous black subjects is absent from Chinodya's Harvest of Thorns. When he comes back home to the new national space-time he contributed to shaping, Benjamin finds that, if any change has occurred, it is either limited or negative: his mother is separated from his father, they still live in the township, he still sees opulent houses from the window of a crowded omnibus (6), he still has no job or house, and he still has adulthood to cope with. The novel ends with Benjamin's newly born son, whom he calls Zvenyika (roughly translated as "things of this country" or "politics"), which, in this context, is a sign of resigning the fate of the country to forthcoming generations. The future of the country, of Benjamin and of Zvenyika, remains uncertain - even dystopian - given that the story ends with Benjamin still yet to secure a job. The emerging national space is characterized by "betrayal of the promises of independence" (Mangena 894). The novel becomes a verdict on the failed construction of the utopian national space called home:

The worst thing is to come back and find nothing has changed. I look at my father and mother and brother and sister, at the house in which I was born, at the township in which I grew up - people prefer to call it suburb now - and I see the same old house, the same old street and the same old faces struggling to survive. (Chinodya 272)

The disaffected ex-combatant is a far cry from the "the gallant soldier in the fight for our liberation" usually eulogized at the burials of those deemed to be national 
heroes in Zimbabwe by the ruling party (Gappah 5). The home to which he comes is further away from this official discourse. His relationship to the much peddled ideas of land and nation is contradictory. The story has disillusionment as its main bedrock.

In Coming Home, we see the euphoria of returning from war to a new nation and heralding a new day in returning from exile; that euphoria is virtually absent from Harvest of Thorns. Chinodya himself, in his interview with Flora Veit-Wild, defends his depiction thus: "I'm not sure what they mean by 'negative picture of independence.' If that means showing, at the end of Harvest of Thorns, a dejected and unemployed ex-combatant, a torn family and a wounded nation, then I don't think that is negative at all. That's reality" (qtd. in Veit-Wild 322). The changing colour of the enemy in the postcolonial period destroys the easy dichotomy of colonizer and colonized, a dichotomy on which Maruma greatly relies in his narrative. Benjamin soon learns through his experiences in the war that the mythological "collective," a favourite of nationalism and often represented by the family in literary work, does not exist. A functional family represents a functional nation. However, the dystopian family to which Benjamin returns represents the dystopian nature of the nation. The voices of dissonance among the guerrillas themselves deconstruct the images of a collective group of ideologically correct fighters; this predicts and signifies the postcolonial dystopian condition of the new nation. The deconstruction of ideological illusions is so strong that Benjamin's homecoming lacks the pomp and fanfare that nationalistic ritualism accords most such heroic returns. The ritualization of the memory of guerrillas is usually done in August in Zimbabwe, and, on this day, guerrillas are praised for setting the country free. ${ }^{8}$ Instead of praising him, Benjamin's mother pesters him for being a loafer after wasting his time in the bush while those of his age, the

\footnotetext{
${ }^{8}$ This day is called Heroes' Day, during which the ZANU (PF) government gathers people (usually ZANU [PF] supporters) at the National Heroes Acre (where those conferred with the national hero status are buried when they die) to remember and celebrate the sacrifices of these "gallant" and "selfless" "sons and daughters of the soil." The ritual, during which president Mugabe delivers a speech, is aired live on national television.
} 
current bureaucratic drivers of the dystopian nation, were getting some education (Chinodya 24).

The movement towards deconstructing hegemonic discourses of heroic, post-war homecomings agrees with Helen Tiffin's concept of "disidentification," which, in this case, is a way of fragmenting the neat binary of home as authentic and foreign spaces as inauthentic (qtd. in Hochbruck 135). What was supposed to be an authentic home space to which Benjamin returns instead harbours colonial "[m]isharvests" (Hochbruck 132), which even the rhetoric, traditions, and cultural schemes of nationalist ideologies of the war cannot hide. The bureaucratic running of the new nation, based on exclusions and inclusions by men in blue suits, with briefcases, flashy cars, and numerous mistresses (Chinodya 17), has potential for the alienation of this guerrilla.

Of particular interest is Benjamin's return to family life, which is characterized by the absence of the father figure he left behind. Benjamin's father is now a peripheral figure in his life; he no longer runs Benjamin's life the way he did before Benjamin went to war. His mother mourns the absence of her husband, who has gone off with another woman $(9 ; 22)$. In fact, since Benjamin's arrival, his father has not made time to come and see him. The house itself is dystopic, as shown through his mother's mourning: "I don't know what it is I did in this world to deserve this. First you disappear from home. Then your father packs up. Then your sister runs off with a man I haven't seen. Now you come back to tear apart the little I've tried to hold together" (23). To exit home, without the father's approval, and to come back with no fatherly remonstration is in a way a fatherkilling exercise and an indictment as well of both fatherhood and home. The "crisis of manhood," brought about by abusive and hegemonic fathers (Muponde and Muchemwa xx), is challenged by Benjamin. He exits home to get out of the space that is under the hegemonic control of his father, who runs a very oppressive regime at home. However, Benjamin does not have the power (at that moment) to extricate himself from the claws of his father's hegemony. The war 
offers Benjamin an escape route so that, when he comes back, he is his own man now with no nativist and essentialist shibboleths associated with a life manned by fathers. The fact that Benjamin is tearing apart everything his mother has been desperately holding together is a way of reinventing his story. The war has made Benjamin free in the sense of having conferred on him the ability to run his life outside the control of his father. Unlike Peter, his crippled brother, Benjamin can even operate outside the authority of his mother: "Look Mother, you know I drink. Peter knows I drink. So what's the point of hiding it?" (23).

There are seeds here for what Wilson Harris terms "re-visionary potential," that is, the potential to revise and invert the script of nationalism (19). This potential to subvert Zimbabwean nationalism is contained in the fact that the family is a symbolic representation of the nation; its dystopic nature and the rebellion of the son speak to the absence of what Elleke Boehmer calls "talismans of fatherly power" in nationalist histories (qtd. in Muponde, "Opinion" 522). The lack of unitary order in the family that Benjamin comes back to opposes the utopian idealization of the post-Chimurenga home in nationalist literature like Coming Home. However, this potential to subvert the talismanic power of fatherhood has its limits too, principally because Benjamin is now a father, and the father from whose authority he has walked out reincarnates in him to enact this authority on his newborn son, Zvenyika. Also, even though Benjamin is no longer within the orbit of his father's power, he still circulates in geographies manned by fathers whose presence already has adverse effects on him, one of which is his failure to secure a job in the new corrupt bureaucracy.

Even though Benjamin's exit to war against his father's will can be read as a subversion of fatherly authority, it is also apparent that he loses the battle on two fronts. First, his outward move defies his father, yet he remains trapped within the broader fatherhood of Zimbabwean nationalism, which he helps put to power by fighting its war in the bush. When he comes back, it is this fatherhood that presides. In a way, Benjamin's homecoming is a journey back to the beginning. It 
is a beginning in the sense that what Benjamin was dealing with (white authority) during the war was removed to pave way for another kind of authority, another kind of dystopia. There is no glory, therefore, in coming back home, even though Maruma tries very hard to demonstrate in Coming Home that Zimbabweans' future home, in the hands of the new fathers, is utopian. On the last page of the novel, Simon states how the independence of black people in Zimbabwe is hated by "some bitter enemies," meaning white people, whose "poisonous heads had not been chopped off," but he declares that "our new black government was vigilant and on top of the situation" (143), a militarized statement meant to convince the reader that the current leadership is ideal.

The old home, with its father and its religious regime that sought to cleanse Benjamin of demons, and the new fatherless home, with the son becoming the father, subvert the nationalist tautology of the colony as dystopian and independence as utopian because the postcolonial space is as dystopian as the old one. The dystopia of the old home makes Benjamin regret a childhood that was messed up by crises:

I never had the chance to experience what other young men experienced. The church robbed me of my childhood and the war took away proper school, friends, holidays and all that. One day I was a teenage student doing prep in the dorm. The next I was a guerrilla shooting Smith's soldiers in the bush. And before I even knew it, I was bringing home a wife. (273)

His interrupted childhood also means he will forever remain young, like his nation, which continues to peddle the discourse of freeing its own sovereignty and continuing with the Chimurenga several decades after its independence. Muponde analyzes depictions of childhood in Zimbabwean literature while also subtly suggesting that the nation remains in some kind of eternal childhood in Some Kinds of Childhood: Images of History and Resistance in Zimbabwean Literature (2015). Benjamin's homecoming cannot be read as an entirely new beginning, as the narrator in Coming Home tries so hard to prove, but rather as the story of a journey 
back to the old beginning, in a way that shreds any utopian visions of the future. The nation remains young.

Why would Maruma miss this when, unlike Chinodya, he had the advantage of hindsight? Writing "out of period," as it were, Maruma ought to be more expansive and practical in the way that he handles independence concerns. Coming Home uses ZANU ( $\mathrm{PF}$ )'s propaganda to sanitize its legacy in politically volatile times inasmuch as it is part of the party efforts to celebrate past ideals and successes presided over by its leadership. Having stayed in England, Simon is alienated by the racial bias he has to endure, and he realizes that home can only be southern Rhodesia. The rejection by Britain bolsters his position that black people are justified in demanding back the only home that they know. Out of this experience grows distaste for the whites who reject him yet still freely walk his country. His encounter with menacing Rhodesian soldiers singing the racist "Rhodesians Never Die" at his cousin Samson's flat confirms to Simon that white attitudes remain alive, and this hardens him against them (18-19). His bad exilic experiences account for the euphoria with which he looks at home when in exile and the glowing tributes he gives to it once he is back. Brian Chikwava's narrator in Harare North (2009) comes to a similar assessment of Britain in relation to Zimbabwe. The difference between his and Maruma's characters is that the narrator in Chikwava knows enough of home to realize that it is not a paradise.

Oliver Nyambi suggests that this indictment of the British is deliberately set out at the start of the novel to stress the idea that British presence inevitably brings problems to African people (146), a position that comes in handy in dealing with and even warding off accusations that might be levelled against the black leadership. Conjuring up images of a racist Britain - both in the metropolis and in southern Rhodesia, where white is set against black - is crucial in shaping and aligning issues of race and the possible responses to it in the present strife. In the novel, whites are cast as unenviable, irredeemable, and deserving of exclusion, and this is stressed when their conduct is set against the ennobling depiction of 
the blacks. Maruma curtails the emergence of alternative narratives the moment he suggests that it is only the presence of the whites that stymies black people's development.

Maruma subtly suggests that a struggle similar to the liberation war is imperative to deal with current problems. Waging another struggle entails trusting "tested" and "proven" leaders who have liberated the country before and who know how best to deal with whites. Casting this in any other way would imply that the country is grappling with new challenges, which would suggest the need for new ways of dealing with them and thus lessen the role of past liberators in the present. Put simply, this was ZANU (PF)'s way of remaining relevant and coalescing support around it at a very difficult time politically and economically. The novel conflates the importance and also legitimizes the continued rule of the present leadership, during a time when, in nationalist parlance, past problems have reared up, until such a time when these problems have been dealt with (like they were dealt with in the past). The post-1999 land occupations are thus a logical continuation of this war and ought to be celebrated as such. Maruma asks the public to forget the intervening years that in reality might have caused the present problems and the role that the leaders of the day have played in the genesis of these problems. Harvest of Thorns, on the other hand, uses the neglect of Benjamin by men in blue suits (the new black leaders) as a microcosmic representation of the neglect the country has suffered at the hands of its leaders. Thus, the centrality of the leaders in the genesis of the country's misharvests is foregrounded in Harvest of Thorns.

Further to that, Coming Home focuses on a moral argument that is an index of race relationships in Zimbabwe: Prince Charles is seen with a married woman, Camilla Parker Bowles; Lord Soames is "bonking one of the foreign correspondents" (92); and the Swedish lady journalist seems to be a serial bedhopper. The novel conveniently reminds the public of British inadequacies in efforts to resolve issues in Zimbabwe. Maruma takes away Britain's moral 
standing through this presentation of a British leadership that fails even to manage its own selfish desires, a leadership with a penchant to cheat its partners and which therefore cannot be expected to be just and honest in approaching Zimbabwean issues. Maruma makes it clear that the morally compromised British have no standing to lecture Zimbabwe on what is right or wrong at this time.

The western media is also not spared this shellacking. Correspondents spend most of their time drunk, taking hard drugs, and bed-hopping. Bill Simpson, the assistant editor of the Sunday Mail, is rabidly racist and clearly prejudiced against blacks and the incoming black leadership. Maruma's novel is thus a "grand project to (re)cast whites as perpetual enemies of the nation and therefore justifying their expulsion from it as an act in the "national interest'" (Nyambi 161). What is depicted as the absence of integrity and control on a personal level is translated to intimate a lack of credibility in reportage on Zimbabwe. This media condemnation attacks the alternative source of reporting on the situation in the country and delegitimizes any reports that question the current black leadership. It is as if whites have forfeited the right to comment on Zimbabwe, which leaves the onus on people like Simon.

Those black leaders who represent an alternative viewpoint in the politics of colonialism and who, like Maruma, know no other home - black leaders like Bishop Muzorewa, Ndabaningi Sithole, James Robert Chikerema, and Chief Chirau - are dismissed as stooges of the whites and not fit to hold office in independent Zimbabwe: "The day they agreed to cooperate with [white Rhodesian Prime Minister] Ian Smith, they were all finished" (102). Their "link" to the whiteness that has been roundly condemned thus far casts them as sell-outs of the cause who have no right to think that Zimbabweans should support them when there is a chance that they would return the country to the whites. By association, this then casts the alternative leadership of the Movement for Democratic Change 
$(\mathrm{MDC})^{9}$ as similar and thus not fit to hold office because of their perceived whiteness, which compromises their claims to be representative of the people's cause. For daring to imagine a home different from the one they are allowed space in, they are labelled and marginalized. This disturbing desire to exclude everyone else, to soil everyone else's reputations but those of the nationalist leaders, and to increasingly look to these present leaders as the messiahs of the country are what narrow the conception of nation and vest a limited group of people with the keys to determining the nation's destiny.

In spite of the varied challenges they have to grapple with, Maruma relives a past where black people show huge potential to survive and to succeed. Samson is typical of those blacks who have made it. Living in the Avenues, formerly an allwhite enclave, Samson's meteoric rise in life is attributed to the liberation war that has forced "Smith and his cohorts [...] to grudgingly concede that the days of racial segregation were over" (2). Now he has a good job for one of the big insurance companies in Harare, something which remains a pipe dream for the nearly destitute Benjamin, who ironically made sacrifices in the war to free similar opportunities for himself and other black people. This is what independence promises for only some blacks in Zimbabwe. This shift is apparent as the preindependence "sombre mood of uncertainty [which] had hung over the country like a dark cloud" is replaced by "a palpable new feeling of hope and optimism [which] swept through the country" (133).

These are the fresh, intoxicating shifts that Maruma wants the readers to revel in. However, what especially jars about this reminder of some sort of debt the country owes to its liberators is the insinuation that it is for the best to keep trusting those who were the custodians of this vision during the struggle. The eulogizing and valorization of the black liberators, to have greater potency, is simultaneously paralleled with a vilification of the whites and black sell-outs who

\footnotetext{
${ }^{9}$ The MDC is an opposition party formed in the late 1990 s from the country's labour movement. It is led by Morgan Tsvangirai and has, since its formation, represented ZANU (PF)'s arch-enemy. However, it has virtually failed to dislodge ZANU (PF) either through elections or mass demonstrations.
} 
are seen as responsible for the problems that crippled black advancement then. In one clever stroke, Maruma has both celebrated and legitimized the current ZANU (PF) leadership while castigating and laying the blame for current ills on the "Rhodies" 10 and their cohorts who have refused to let go of their ill-gotten privileges. Despite this, there is sadly not enough that is tangible about home to celebrate. Almost unconsciously, Maruma seems to admit to the fact that there is actually nothing worth writing about at home, in itself an admission of the 2007 realities that he tries unsuccessfully to wish away. Coming Home becomes more about what makes home the way it is and less about what home actually is like.

The ingenuity of the novel comes with the position that Maruma gives to Simon. Simon's law degree makes him the public face of rationality and justice, and his arguments gain weight because of that. That he also obtained his degree from England ironically validates his assessment of white thinking and attitudes. He thus comes across as a genuinely credible, intellectual voice to account for the socio-economic and political realities of the transition period. Such intellectualism is crucial as it "enlists the reader's sympathies to identify with his [Simon's] opinion" (Nyambi 146). And further to this, his pronouncements, like his varied arguments to deflate whites and white rule, are not removed from fact. He takes every opportunity he gets to preach and to tutor the populace on the injustices of white ways, and even the prostitutes in bars are not spared. Ironically, Simon himself is steeped in white ways, something that an observant reader would use to read Simon's discourse with suspicion. The weight of the ZANU (PF) narrative is thus accentuated by the intelligentsia, replacing the hip-wiggling women and placard-carrying party sycophants who might not be taken seriously by the electorate that the party seeks to win over. Narrators like Simon, together with the academic historians that Terence Ranger identifies, represent those intellectuals who have been recruited by the patriotic historical discourse to lend it weight and legitimacy and to gain it leverage and support. Intellectuals are thus used in the

\footnotetext{
${ }^{10}$ This is the name given to ex-Rhodesians (usually white) or blacks with Rhodesian sensibilities.
} 
battle to retrieve past memory and to argue for its continued relevance and ascendancy in dealing with present circumstances.

The depictions of home from the two texts analyzed above are thus contradictory. Coming Home, published twenty-seven years after independence during a dystopian period, seems to glorify a period that Harvest of Thorns did not celebrate. By doing so, Maruma functions within the ambit of Zimbabwean nationalism. His work comes across to the reader as a project for nationalist propaganda. Chinodya's, on the other hand, does not glorify homecoming and thus opens up avenues for the subversion of nationalist historiography which Maruma's Coming Home seems to be supporting. Coming Home, written at a period when many Zimbabweans were emigrating due to crisis, reads like a homecoming project meant to counter the dystopian reality that was chasing people from Zimbabwe at that time. The dystopian reality that Harvest of Thorns depicts can be regarded as a post-national moment that opens avenues for what Muponde calls "a narrative revolution that will throw up new questions of history, resistance, and cultural politics in Zimbabwe" (Some Kinds 129). There is a negation of home being known in advance so that homecoming lacks the certainty that Coming Home entertains. However, the fact that the subversion and shattering of homebound ideologies that we encounter in Harvest of Thorns is countered eighteen years later by Maruma in Coming Home points at the simultaneous or dialectical existence of articulation (nationalism/utopia) and disarticulation (post-nationalism/dystopia). Thus, just as a tropistic writing of home and homecoming exists (in Coming Home), so does subversive writing of home and homecoming (in Harvest of Thorns), both in the same space and sometimes at the same time. Therefore, post-nation cannot be understood in terms of the atrophying of nation. Nation and postnation are just two of the many multifarious and contradictory conditions of the postcolonial world that exist simultaneously but also dialectically. 


\section{Works Cited}

Abu-Shomar, Ayman. "Critical Spaces of Diaspora for Liquid Post-Modernity." Journal of Postcolonial Cultures and Societies, vol. 14, no. 13, 2013, pp. 1-14.

Chikwava, Brian. Harare North. Jonathan Cape, 2009.

Chinodya, Shimmer. Harvest of Thorns. Baobab, 1989.

Gappah, Petina. An Elegy for Easterly. Faber, 2009.

Gomo, Mashingaidze. A Fine Madness. Ayebia Clarke, 2010.

Hammar, Amanda, Brian Raftopoulos, and Stig Jensen. Zimbabwe's Unfinished Business: Rethinking Land, State and Nation in the Context of the Crisis. Weaver, 2003.

Harris, Wilson. "The Fabric of the Imagination." From Commonwealth to PostColonial: Critical Essays, edited by Anna Rutherford, Dangaroo, 1992, pp. 18-29. Hochbruck, Wolfgang. "The Changing Colours of the Enemy in Zimbabwean War Fiction." War and Literature, vol. 6, no. 11/12, 1994, pp. 131-36.

Kanengoni, Alexander. "Ode to a Misunderstood Friend." AllAfrica, 14 Jan. 2010, http://allafrica.com/stories/201001140721.html.

Katiyo, Wilson. A Son of the Soil. Rex Collings, 1976.

Mangena, Tendai. "Selected Zimbabwean Writings and the Politics of Counter-

Discourse in Post-Independence Period." European Journal of Humanities and Social Sciences, vol. 18, no. 1, 2012, pp. 890-902.

Marechera, Dambudzo. The House of Hunger. Heinemann, 1978.

Maruma, Olley. Coming Home. Gonamombe, 2007.

Mtizira-Nondo, Nyaradzo. The Chimurenga Protocol. Botshelo, 2008.

Mungoshi, Charles. Waiting for the Rain. Heinemann, 1975.

Muponde, Robert. "Opinion, Dialogue, Review: Unhappy Family, Unhappy

Children and the End of Childhood in Dambudzo Marechera's The House of

Hunger." Childhood, vol. 13, no. 4, 2006, pp. 519-32.

-. Some Kinds of Childhood: Images of History and Resistance in Zimbabwean Literature. Africa World, 2015. 
Muponde, Robert, and Kizito Z. Muchemwa. "Introduction: Manning the Nation." Manning the Nation: Father Figures in Zimbabwean Literature and Society, edited by Robert Muponde and Kizito Z. Muchemwa, Weaver, 2007, pp. xv-xxiii.

Muponde, Robert, and Ranka Primorac. Versions of Zimbabwe: New Aproaches to Literature and Culture. Weaver, 2005.

Mutambara, Agrippah. The Rebel in Me: A ZANLA Guerrilla Commander in the Rhodesian Bush War. Helion, 2014.

Ndlovu-Gatsheni, Sabelo J. "Making Sense of Mugabeism in Local and Global Politics: 'So Blair, Keep Your England and Let Me Keep My Zimbabwe." Third World Quarterly, vol. 30, no. 6, 2009, pp. 1139-58.

Nyambi, Oliver. "Re-Imagining and Re-Casting 'Us' and 'Them': The Novel Coming Home and the Contemporary Resurgence of Race-Inspired Nationalism in Zimbabwe's Past Decade." Africana, vol. 6, no. 1, 2012, pp. 141-67.

Primorac, Ranka. The Place of Tears: The Novel and Politics in Modern Zimbabwe. Tauris, 2006.

Raftopoulos, Brian. "The Crisis in Zimbabwe, 1998-2008." Becoming Zimbabwe: A History from the Pre-Colonial Period to 2008, edited by Brian Raftopoulos and Alois Mlambo, Weaver, 2009, pp. 201-232.

Ranger, Terence. "Nationalist Historiography, Patriotic History and the History of the Nation: The Struggle over the Past in Zimbabwe." Journal of Southern African Studies, vol. 30, no. 2, 2004, pp. 215-34.

Vambe, Maurice T. "Race and Land Ownership in Rhodesia: Trajectories of Conflicting Nationalisms in Shimmer Chinodya's Dew in the Morning." Development Southern Africa, vol. 24, no. 2, 2007, pp. 257-70.

Veit-Wild, Flora. Teachers, Preachers, Non-Believers: A Social History of Zimbabwean Literature. Baobab, 1993.

Zhuwarara, Rino. An Introduction to Zimbabwean Literature in English. College, 2001. 
Zimunya, Musaemura Bonas. Those Years of Drought and Hunger: The Birth of African Fiction in English in Zimbabwe. Mambo, 1982.

Tanaka Chidora is a lecturer in the Department of English, University of Zimbabwe. His research interests include popular culture, literature and resistance, postcolonial literature, and Zimbabwean migrant narratives; his current research focuses on post-2000 literary narratives by Zimbabwean writers that centralize issues of exile, space, and belonging. He has written on manifestations of resistance in Zimdancehall, a youthful musical genre and movement in Zimbabwe. Forthcoming publications include an exploration of the schizophrenias of Zimbabwean writing.

Sheunesu Mandizvidza teaches undergraduate courses in the Department of English, University of Zimbabwe. His research interests include issues of home and exile, belonging, and land literature concerns. He is currently co-editing a book on multi-disciplinary approaches to gender in Zimbabwean society. His doctoral research focuses on the intersection of literature and history in the depiction of the post-2000 Fast Track Land Reform Programme. 